\section{OPTIMUM TILT ANGLE FOR MAXIMIZING LARGE SCALE SOLAR ELECTRICAL ENERGY OUTPUT}

\author{
Mohamed Nagehb, Md Pauzi Abdullaha,b, Belal Yousefc
}

aCentre of Electrical Energy Systems (CEES), Institute of Future Energy (IFE), Universiti Teknologi Malaysia, 81310 UTM Johor Bahru, Johor, Malaysia

bSchool of Electrical Engineering, Faculty of Engineering, Universiti Teknologi Malaysia, 81310 UTM Johor Bahru, Johor, Malaysia cSystem Analyst, Saudi Xerox, Khobar, Saudi Arabia
Article history

Received

28 October 2020

Received in revised form

25 March 2021

Accepted

6 April 2021

Published online

20 April 2021

*Corresponding author nageh@graduate.utm.my

\section{Graphical abstract}

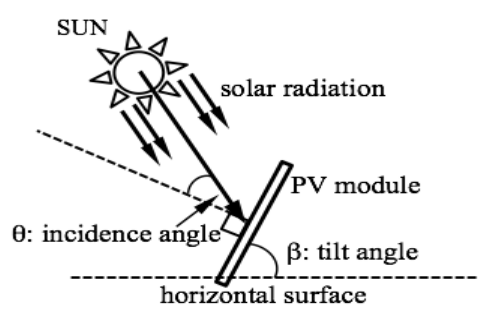

EARTH

\begin{abstract}
Many large-scale solar (LSS) plants that are being installed today have solar photovoltaic (PV) panels mounted on fixed structures, which limits its electrical energy production. Tracking system can be installed so that the PV panels could change its tilt angle automatically in accordance with the sun's movement. However, it will increase the construction, operation and maintenance cost significantly. Another option is to manually adjust the tilt angle on periodically basis, but the time period and the optimum tilt angle need to be systematically determined. This paper investigates the impact of using monthly and seasonal optimum tilt angle, $\beta_{\text {opt }}$ on electrical energy production of LSS plant. The proposed strategy can be implemented by using tiltable solar panel mounting structures which is far cheaper than the tracking system. For the study, $1 \mathrm{MW}$ LSS system model is used. Twelve cities around the globe with latitude angle ranging from $0^{\circ}$ to $55^{\circ}$ are strategically selected. The electrical energy output from the 1 MW LSS plant is simulated by using PV mathematical model that is developed in Matlab software. The overall results show that by adjusting the tilt angle of the PV modules into its optimum angle on monthly or seasonal basis, it would increase the generated energy output between $1.91 \%$ and $7.24 \%$ for monthly adjustments and between $1.59 \%$ and $6.06 \%$ for seasonal adjustments.
\end{abstract}

Keywords: Large scale solar, tilt angle, energy output, solar PV performance

\begin{abstract}
Abstrak
Banyak loji suria berskala besar (LSS) yang dipasang hari ini mempunyai panel solar fotovoltaik (PV) yang dipasang pada struktur tetap, yang membatasi pengeluaran tenaga elektriknya. Sistem penjejakan dapat dipasang sehingga panel PV dapat mengubah sudut kecondongannya secara automatik sesuai dengan pergerakan matahari. Namun, ia akan meningkatkan kos pembinaan, operasi dan penyelenggaraan dengan ketara. Pilihan lain adalah menyesuaikan sudut kecondongan secara berkala secara manual, tetapi jangka masa dan sudut kecondongan optimum perlu ditentukan dengan sistematik. Makalah ini menyelidiki kesan penggunaan sudut kecondongan optimum bulanan dan bermusim, ßopt kepada keluaran tenaga elektrik loji LSS. Strategi yang dicadangkan dapat dilaksanakan dengan menggunakan struktur pemasangan panel suria yang dapat dicondongkan yang jauh lebih murah daripada sistem penjejakan. Untuk kajian ini, model sistem LSS 1 MW digunakan. Dua belas bandar di seluruh dunia dengan sudut lintang antara $0^{\circ}$ hingga $55^{\circ}$ dipilih secara strategik. Keluaran tenaga elektrik dari loji LSS 1 MW disimulasikan dengan menggunakan model matematik PV yang dibangunkan dalam perisian Matlab. Dapatan keseluruhan menunjukkan bahawa dengan menetapkan
\end{abstract}


sudut kecondongan modul PV ke sudut optimumnya secara bulanan atau bermusim, ia akan meningkatkan keluaran tenaga yang dihasilkan antara $1.91 \%$ hingga $7.24 \%$ untuk tetapan bulanan dan antara $1.59 \%$ hingga $6.06 \%$ untuk tetapan musiman.

Kata kunci: Suria skala besar, sudut kecondongan, keluaran tenaga, dan prestasi solar PV

(c) 2021 Penerbit UTM Press. All rights reserved

\subsection{INTRODUCTION}

There are many factors that affect the electrical energy output of a large scale solar (LSS) PV plant. Many of these factors cannot be controlled such as solar irradiance, sunshine hours, temperatures and humidity as it depends on plant location. Other factors can easily be implemented such as solar module efficiency and inverter efficiency. Another important factor is the tilt angle of PV panel, which has significant impact on energy output from LSS plant. Orienting the PV module in a direction and tilt in order to maximize its exposure to direct sunlight will optimize the collection performance. The PV module will collect the solar radiation most efficiently when the sun's rays are perpendicular to the module's surface. However, the angle of the sun varies throughout the day, thus it is impossible to maintain the sun's ray perpendicular to the module's surface. Solar tracking system would overcome the problem as it is able to track the sun's movement and automatically adjust the tilt angle of PV module via its single/dual axis motoring system. But having a tracking system for LSS plant would increase the construction cost dramatically. It also increases the operation and maintenance cost. Due to these reasons, fixed tilt angle PV module is preferred for LSS plant. The tilt angle is optimized in such a way that the LSS could reach its maximum energy production.

The angle of the sun does not only vary throughout the day, it also varies from month to month and season to season. Thereby, the $\beta_{\text {opt }}$ during summer will differ from winter. Fixing permanently the tilt angle will limit the true potential of energy production from LSS plant. The tilt angle should be allowed to be adjusted manually on monthly or seasonal basis so that the energy output from LSS plant can further improved. Compared to the expensive automatic solar tracking system, this strategy is far cheaper since it only involves small modification to the PV module structure design. The operation is also simple as the tilt angle can be manually adjusted and thus minimum cost involved. This paper will investigate the monthly and seasonal

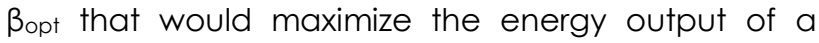
$1 \mathrm{MW}$ LSS PV plant. 12 cities around the world with latitude angle between $0^{\circ}$ and $55^{\circ}$ (5० apart from one to another city) were selected for the study. The detailed PV mathematical model and related equations were developed in Matlab software to simulate the energy output from the LSS plant for each location. The optimized monthly and seasonal tilt angle will be then investigated and compared to the location's latitude angle.

This paper begins by explaining briefly the basic concept and terminology related to tilt angle and previous works. The next section will explain the methodology used for this study, which include the $1 \mathrm{MW}$ LSS plant model, the 12 cities/location, the PV model equations and the method for determining the $\beta_{\text {opt }}$ used in this paper. The section after that will present the results of monthly and seasonal $\beta_{\text {opt }}$ together with the LSS energy output. The results for fixed tilt angle are included for comparison as well as simulation accuracy validation. The last section concludes the findings of this paper.

\section{Optimum Tilt Angle, $\beta_{\text {opt }}$}

The tilt angle affects the solar system output directly. Figure 1 shows the relationship between latitude $(\Phi)$, solar declination $(\delta)$, incidence $(\theta)$ and tilt $(\beta)$ angle. These angles play an important role in the output performance and efficiency of the PV module. Orienting the PV module in a direction of solar radiation will maximize its exposure to direct sunlight and hence its output energy performance. Energy generation can be improved by setting the PV systems inclination to the $\beta$ opt. Previous works related to the $\beta_{\text {opt }}$ (Orientation) of the PV Modules are presented in reference [1-21]. Many previous researches have studied and proposed $\beta_{\text {opt }}$ for different location. Some suggested different $\beta_{\text {opt }}$ for different seasons and for different month to improve the solar PV output.

Researcher in [5] determined the $\beta$ opts for many cities by using NREL's PVWatts program. A third-order polynomial fit for the $\beta_{\text {opts }}$ as a function of latitude was developed from the data of the Northern and Southern Hemispheres.

In [7], the $\beta_{\text {opt }}$ and optimum azimuth angle of photovoltaic (PV) panels were determined by employing the harmony search (HS) meta-heuristic algorithm. In the study, the ergodic method is firstly conducted to obtain the $\beta_{\text {opt }}$ and the optimum azimuth angle in several cities of China based on the model of Julian dating. Next, the HS algorithm is 
applied to search for the optimum solution.

Researcher in [10], used mathematical analysis to determine the monthly, seasonal and annual $\beta_{\text {opt }}$ of PV panels for Bilecik city, Turkey. In [11], the author estimated the global and diffuse solar radiation for the city of Aligarh and New Delhi, India for a period of three years. The monthly, seasonal and annual $\beta$ opt angles were estimated. The annual $\beta_{\text {opt }}$ for Aligarh and New Delhi was found to be $27.62^{\circ}$ and $27.95^{\circ}$ respectively, which are close to the latitude of the location.

The researcher in [12], investigated whether the tilt angle of the solar PV system affects the amount of solar radiation received. The work also presented a simple method to determine $\beta_{\text {opt }}$ by estimating the monthly mean daily global solar radiation on tilted surfaces facing directly towards the equator. It is based on monthly average daily global solar radiation data produced from the typical meteorological year (TMY) data. Six different locations with different climates in China were used to determine the monthly, seasonally and yearly $\beta_{\text {opt }}$ for $\mathrm{PV}$ panels.

Researcher in [13] used an optimization method based on Liu and Jordan model to estimate the solar energy incident on a tilt surface by considering monthly and seasonal tilt angles. Five different sites in Malaysia were used in the study. The results showed that seasonal $\beta_{\text {opt }}$ is recommended for west Malaysia (Peninsular Malaysia), while monthly $\beta_{\text {opt }}$ is recommended for east Malaysia (Sabah and Sarawak).
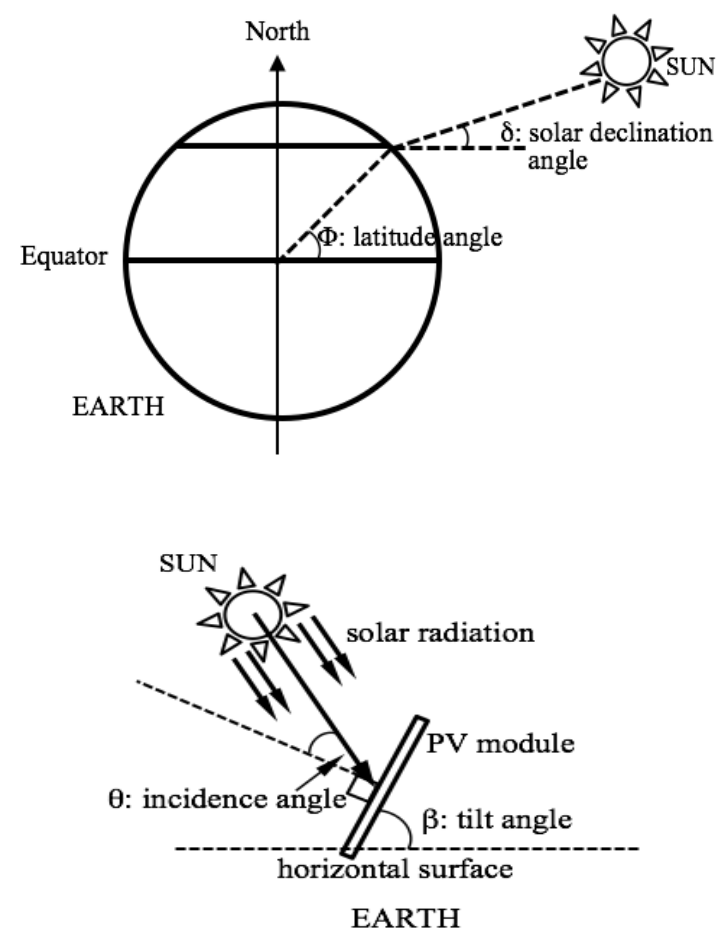

Figure 1 Relationship between latitude, solar declination, incidence, and tilt angle
Due to the rotation of the earth around its orbit and axis, the solar incidence angle varies throughout the year. At the Northern Hemisphere, the solar radiation falls to the earth with steep angle during summer but slight angle during winter. To extract maximum electrical energy from PV modules, the sunlight should fall with steep angle onto the PV modules. Thus, the optimum tilt angle for the PV modules should be changed monthly or seasonally, corresponding to the earth's position against the sun. It is supported by simulation results of previous works mentioned earlier. Most of the previous works used available models, software or simulator to determine the ßopt, such as Liu and Jordan's model, Klien model, Hay and Badescu models, Hay and Davies diffuse model, PVWatts model, GATOR-GCMOM model, Sky models, Isotropic model, Valentin software and PVGIS simulator [1-21].

\subsection{METHODOLOGY}

This section explains the LSS model used in this paper to determine the $\beta_{\text {opt }}$ for 12 selected locations. It also describes the method used in determining the $\beta_{\text {opt }}$. The PV mathematical model is developed by using Matlab software to simulate the energy production from the LSS plant. All related parameters were included in the model such as tilt angle, locations' latitude, solar radiation and temperature etc. The accuracy of this simulation method has been previously validated against practical data for the city of Cairo-Egpt [22]. The difference in PV annual average daily energy output between the simulated and practical measured data is around $5 \%$.

\subsection{Large Scale Solar (LSS) Plant Model}

For this study, the LSS plant model used for the simulation study is $1 \mathrm{MW}$. The total number of PV panels for this model is $2016 \mathrm{PV}$ modules. It consists of $14 \mathrm{PV}$ modules that are connected in series (string) and $144 \mathrm{PV}$ strings that are connected in parallel (array). Each PV module has the following parameters: Maximum Power $\left(\mathrm{P}_{\max }\right)=500 \mathrm{~W}$, Maximum Power Voltage $\left(\mathrm{V}_{\mathrm{mp}}\right)=48.4 \mathrm{~V}$, Maximum Power Current $(\mathrm{Imp})=10.33 \mathrm{~A}$, Open-circuit Voltage $\left(\mathrm{V}_{\mathrm{oc}}\right)=59.3 \mathrm{~V}$, Short-circuit Current $\left(\mathrm{I}_{\mathrm{sc}}\right)=10.54 \mathrm{~A}$, and Module Efficiency at (STC) $=19.51 \%$. The total output energy from the LSS plant is: 2016 modules $\times 500$ $\mathrm{W} /$ module $=1.008 \mathrm{MW}$. The inverter efficiency is considered in this study but the losses are neglected.

\subsection{LSS Plant Location}

Twelve cities are selected for LSS plant installation as study cases. These cities are chosen carefully from different countries worldwide to cover a variety of local climatic conditions. Thus, the LSS plant's energy output performance under different weather conditions i.e. hot, warm, cool, tropical etc. can be 
investigated. Some of the selected cities are located on the Southern Hemisphere and others are located on the Northern Hemisphere. The 12 cities are strategically chosen from latitude of $0^{\circ}$ into $55^{\circ}$ with an increment of $5^{\circ}$.

\subsection{Determination of the $\beta$ opt}

In this paper, the $\beta_{\text {opt }}$ is determined from exhaustive iteration of simulation results. For each location, the tilt angle is firstly set at $0^{\circ}$. Then LSS electrical energy output for each month, season and year is simulated. Then the tilt angle is increased by $1^{\circ}$ and the LSS energy output is simulated again for each month, season and year. The simulation is repeated again and again for a tilt angle of $0^{\circ}$ until $90^{\circ}$ with a step of $1^{\circ}$. The tilt angle that gave maximum energy output for a particular month is the $\beta_{\text {opt }}$ of that month.

Similarly, the tilt angle that gave maximum energy output for a particular season is considered as the $\beta$ opt of that season. In this paper, the seasons are considered as follows: Spring is from March to May, Summer is from June to August, Autumn is from September to November and Winter is from December to February.

For comparison purpose, the energy output result for a (fixed) $\beta_{\text {opt }}$ is also included in this study.

\subsection{Work Flow}

The work presented in this paper is summarized in Figure 2.

\subsection{Mathematical Equations [23-27]}

As given in Figure 1, solar declination angle $(\delta)$ is the angle between the earth orbit and the sun and it is mathematically represented by the following equation:

$$
\delta=23.45 \sin \left[(284+d) /(365.25365) 360^{\circ}\right]
$$

Where, $\mathrm{d}$ is the day order for one year beginning from January $1^{\text {st }}(d=1)$ until December $31^{\text {st }}(d=365)$. The daily direct solar radiation that falls on the titled surface, i.e. the direct solar energy that falls on the titled surface per day, $\mathrm{H}_{D, \mathrm{~T}}$ is given by:

$$
H_{D, T}=H_{D} R_{b}=1.13 R_{b} K_{T} H_{B}
$$

Where, $H_{D}$ is the daily direct radiation that falls on the horizontal surface given by:

$$
\mathrm{H}_{D}=\mathrm{H}_{B}-\mathrm{H}_{d}=1.13 \mathrm{~K}_{\mathrm{T}} \mathrm{H}_{B}
$$

Where, $H_{B}$ is the global solar radiation that measured on the horizontal surface.

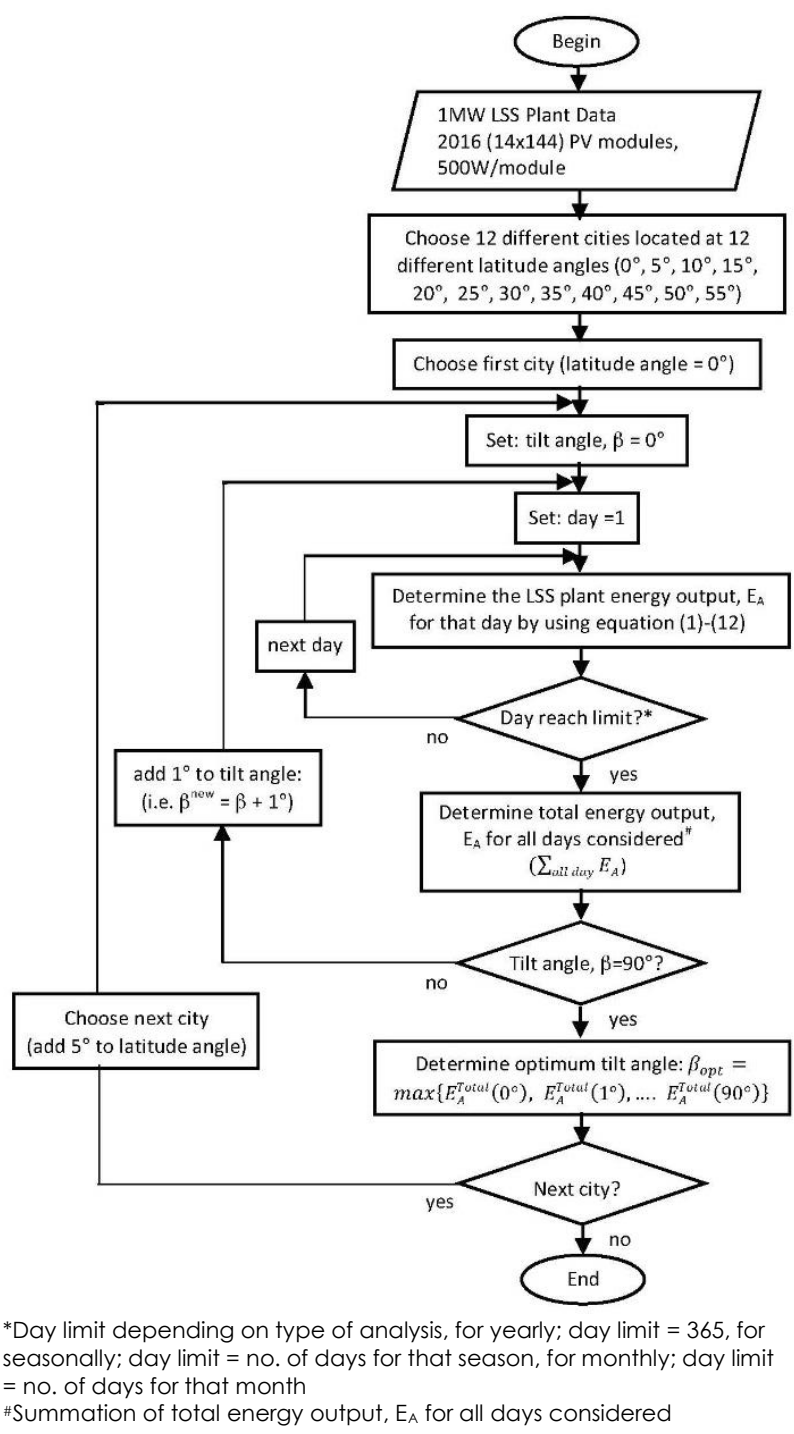

Figure 2 Flowchart of the work

The monthly average daily extraterrestrial solar insolation ( $\mathrm{kWh} / \mathrm{m}^{2} /$ day), $\mathrm{H}_{\text {ext, }}$ is given by:

$$
H_{\text {ext }}=(24 / \pi) G_{s c}\left[\cos \delta \cos \Phi \sin w_{s}+w_{s} \sin \delta \sin \Phi\right]
$$

$\mathrm{H}_{\text {ext }}$ is the energy on the horizontal surface at the same latitude angle. Note that, all solar radiation in the extraterrestrial space is only direct radiation and thus no diffused radiation exists.

The global solar radiation (direct plus diffused) on the tilted surface, the monthly average daily radiation on the tilted surface, $\mathrm{H}_{\mathrm{T}}$ is given by:

$$
\begin{aligned}
& H_{T}=H_{B}\left[1.13 K_{T} R_{b}+0.5(1+\cos \beta)\left(1-1.13 K_{T}\right)+0.5 \rho(1-\right. \\
& \cos \beta)]
\end{aligned}
$$


Where, $\mathrm{K}_{\mathrm{T}}$ is the clearness index of the sky as given:

$$
\mathrm{K}_{\mathrm{T}}=\mathrm{H}_{\mathrm{B}} / \mathrm{H}_{\mathrm{ext}}
$$

The $\mathrm{K}_{\mathrm{T}}$ improves as the sky becomes increasingly clearer.

$R_{b}=\left(\cos \delta \cos (\Phi-\beta) \sin W_{s}^{\prime}+W_{s}^{\prime} \sin (\Phi-\beta) \sin \delta\right) /(\cos$

$\left.\delta \cos \Phi \sin W_{S}+W_{s} \sin \Phi \sin \delta\right) \equiv H_{T} / H_{B}$

Where, $\mathrm{R}_{\mathrm{b}}$ is the ratio between the direct solar radiations on the tilted surface to the horizontal surface $\left(\mathrm{H}_{\mathrm{T}} / \mathrm{H}_{\mathrm{B}}\right)$.

Note that, in case of the normal incident of the solar radiations i.e. the solar radiations will fall on the horizontal surface, thus, the tilt angle of the PV module/s ( $\beta=$ zero degree), thus, both of the tilted and the horizontal angles of incidence are equal $\left(\theta_{T}\right.$ $\left.=\theta_{h}\right)$, and thus, both of the tilted and the horizontal solar radiations are equal $\left(\mathrm{H}_{T}=\mathrm{H}_{B}\right)$, based on all of those; $\left(\mathrm{Rb}_{\mathrm{b}}=1\right)$.

$$
G_{e x t}=G_{s c}[\cos \delta \cos \Phi \cos w+\sin \delta \sin \Phi]
$$

Where, Gext is the solar irradiance on horizontal extraterrestrial surface with constant value $=1.35$ $\mathrm{kW} / \mathrm{m}^{2}$ i.e. Power. Meanwhile, the maximum solar irradiance on earth's surface when the solar beams are normal to the surface is $1 \mathrm{~kW} / \mathrm{m}^{2}$ at the sea level. That means, about $25 \%$ of the extraterrestrial radiation is lost by absorption in the atmosphere, where, $G_{s c} / G_{\text {ext }}=1 / 1.35=0.75$, which means, about $75 \%$ only from solar beams can reach to the ground as well as the surface of PV module/s. The instantaneous global solar radiations on the tilted surface, i.e. instantaneous solar power $\left(\mathrm{kW} / \mathrm{m}^{2}\right), \mathrm{GT}_{\mathrm{T}}$ is given by:

$G_{T}=(\pi / 24) H_{T}\left(\cos W-\cos W_{s}^{\prime \prime}\right) /\left(\sin W_{s}^{\prime}-W_{s}^{\prime} \cos W_{s}^{\prime \prime}\right)$

Then, the array current, $\mathrm{I}_{\mathrm{A}}$ (amp), the array power, $P_{A}$ (watt), and the array energy, $E_{A}\left(k W h / m^{2} / d a y\right)$ of the $\mathrm{PV}$, are given by the following equations:

$$
\begin{aligned}
& I_{A}=I_{S C} G_{T}-I_{O}\left(e^{(V N T)}-1\right) \\
& P_{A}=V_{B} \times I_{A} \\
& E_{A}=E_{A}+\left(P_{A} \times \Delta t\right)
\end{aligned}
$$

Where Isc is short circuit current, lo is the diode's saturation current and $V_{B}$ is $P V$ module voltage.

\subsection{RESULTS AND DISCUSSION}

Table 1 and Figure 3 show the $\beta_{\text {opt }}$ for the 1MW LSS plant for each month for 12 different locations. It can be seen that for the month January, as the latitude angle (city location) increases, the $\beta_{\text {opt }}$ increases. The same pattern is observed for February until June but with decreasing $\beta_{\text {opt }}$ values. For June until December, the same pattern is observed but with increasing $\beta_{\text {opt }}$ values. For a number cities i.e. Quito, Terengganu, Kupang and Lusaka (latitude angle between $0^{\circ}$ and $\left.15^{\circ}\right)$, there are months where the $\beta_{\text {opt }}$ is $0^{\circ}$. The corresponding annual average daily energy (monthly) for the 12 cities is given in Table 2, which varies from one city to ather. The highest annual average daily energy is observed for the city of Kupang (6.44 MWh/day) for November while the lowest is for the city of Frankfurt (1.34 MWh/day) for December.

If seasonal $\beta_{\text {opt }}$ is used, the results are given in Table 3 and Figure 4. Generally, it can be seen that for spring, autumn and winter, the $\beta$ opt increases as the latitude angle increases. For summer, the $\beta_{\text {opt }}$ is zero or almost zero for locations with latitude angle between $0^{\circ}$ and $30^{\circ}$. For higher latitude angle, the $\beta_{\text {opt }}$ is increased. The corresponding annual average daily energy for each season is given in Table 4. In general, the generated output energy in the summer that usually comes with the smallest $\beta_{\text {opt }}$ is greater than the generated output energy in the winter that usually comes with the highest $\beta$ opt. While, the generated output energy in spring season is similar or closer to the generated output energy in autumn season and both of them are usually comes with $\beta_{\text {opt }}$ around or close to the latitude angle. In fact, southern hemisphere is inverse mirror to northern hemisphere at the same time. Thus, in northern hemisphere, whenever the sun is close to the earth; in summer season, $\beta_{\text {opt }}$ will be around or close to zero degree, thus maximum generated output energy can be achieved. While at the same time but in southern hemisphere, the sun is so far from the earth; in winter season, $\beta_{\text {opt }}$ will come with large degrees in order to extract higher energy as much as possible.

For a permanent (fixed) PV module, the $\beta$ opt and its corresponding energy output result is given in Table 5. To compare the energy output performance of the monthly, seasonal and fixed $\beta_{\text {opt, the results }}$ from Table 2 and Table 4 are updated in such a way that they give the average energy output per day for one year, as tabulated in Table 6. The results show that the monthly and seasonal $\beta_{\text {opt }}$ are able to increase the energy output of LSS system. For the city of Cairo, the percentage gain is up to $7.24 \%$ for monthly $\beta$ opt and it's up to $5.92 \%$ for seasonal $\beta_{\text {opt. }}$ For Quito, the percentage gain is not much; it is only $1.91 \%$ and $1.59 \%$ for monthly and seasonal $\beta_{\text {opt }}$ respectively. 
Table 1 Optimum tilt angle, $\beta_{\text {opt }}$ (monthly) for 12 cities globally

\begin{tabular}{|c|c|c|c|c|c|c|c|c|c|c|c|c|c|}
\hline \multirow{2}{*}{ City } & \multirow{2}{*}{$\begin{array}{l}\text { Latitude } \\
\text { Angle }\left({ }^{\circ}\right)\end{array}$} & \multicolumn{12}{|c|}{$\left.\beta_{\text {opt for Month ( }}{ }^{\circ}\right)$} \\
\hline & & Jan & Feb & Mar & Apr & May & Jun & Jul & Aug & Sep & Oct & Nov & Dec \\
\hline Quito & 0 & 23 & 14 & 2 & 0 & 0 & 0 & 0 & 0 & 0 & 9 & 21 & 25 \\
\hline Terengganu & 5 & 28 & 20 & 7 & 0 & 0 & 0 & 0 & 0 & 2 & 13 & 21 & 26 \\
\hline Kupang & 10 & 40 & 26 & 12 & 0 & 0 & 0 & 0 & 0 & 7 & 25 & 40 & 46 \\
\hline Lusaka & 15 & 45 & 32 & 16 & 2 & 0 & 0 & 0 & 0 & 12 & 30 & 44 & 50 \\
\hline Vitória & 20 & 53 & 38 & 20 & 8 & 3 & 1 & 1 & 5 & 14 & 29 & 46 & 55 \\
\hline Doha & 25 & 51 & 41 & 25 & 12 & 2 & 0 & 1 & 9 & 22 & 36 & 47 & 53 \\
\hline Cairo & 30 & 59 & 47 & 32 & 16 & 4 & 0 & 2 & 12 & 27 & 42 & 55 & 63 \\
\hline Tokyo & 35 & 68 & 54 & 35 & 19 & 9 & 9 & 11 & 17 & 25 & 42 & 60 & 72 \\
\hline New York & 40 & 86 & 70 & 53 & 35 & 20 & 14 & 20 & 31 & 47 & 63 & 79 & 90 \\
\hline Milan & 45 & 88 & 74 & 58 & 40 & 26 & 20 & 24 & 37 & 51 & 66 & 81 & 90 \\
\hline Frankfurt & 50 & 87 & 77 & 60 & 44 & 32 & 28 & 31 & 42 & 54 & 69 & 82 & 89 \\
\hline Copenhagen & 55 & 90 & 81 & 66 & 50 & 37 & 32 & 35 & 47 & 60 & 75 & 88 & 90 \\
\hline
\end{tabular}

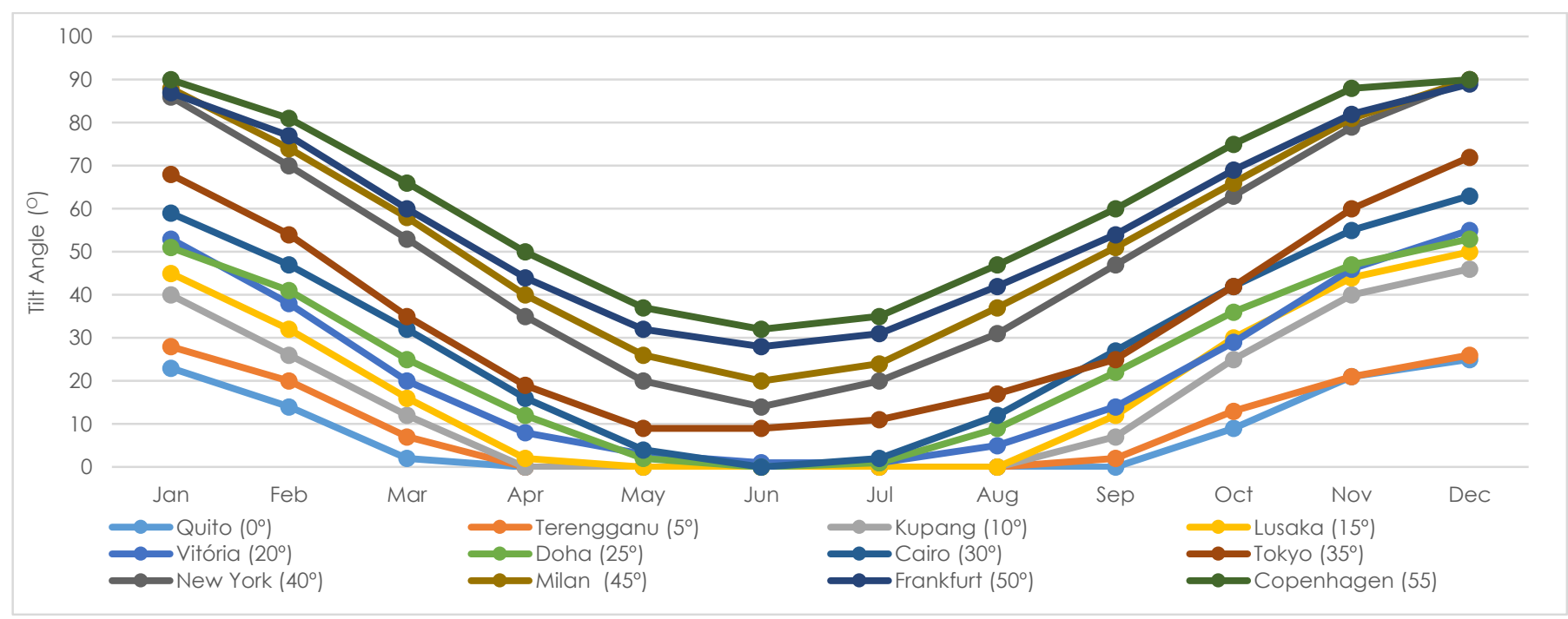

Figure 3 Optimum tilt angle, $\beta_{\text {opt }}$ for each month for 12 cities (located at different latitude angles)

Table 2 Annual average daily energy (monthly) for 12 cities globally

\begin{tabular}{|c|c|c|c|c|c|c|c|c|c|c|c|c|c|}
\hline \multirow{2}{*}{ City } & \multirow{2}{*}{$\begin{array}{l}\text { Latitude } \\
\left.\text { Angle ( }{ }^{\circ}\right)\end{array}$} & \multicolumn{12}{|c|}{ Annual Average Daily Energy Output for Month (MWh/day) } \\
\hline & & Jan & Feb & Mar & Apr & May & Jun & Jul & Aug & Sep & Oct & Nov & Dec \\
\hline Quito & 0 & 3.15 & 3.24 & 3.37 & 3.15 & 2.95 & 2.92 & 3.09 & 3.28 & 3.09 & 3.10 & 3.29 & 3.03 \\
\hline Terengganu & 5 & 3.05 & 3.72 & 3.74 & 3.74 & 3.24 & 3.01 & 2.97 & 3.08 & 3.20 & 2.71 & 2.15 & 2.18 \\
\hline Kupang & 10 & 4.84 & 3.89 & 4.13 & 3.97 & 3.55 & 3.25 & 3.60 & 4.24 & 4.97 & 5.66 & 6.44 & 5.93 \\
\hline Lusaka & 15 & 5.09 & 4.32 & 3.85 & 3.97 & 3.86 & 3.62 & 3.88 & 4.47 & 4.87 & 5.54 & 5.91 & 5.60 \\
\hline Vitória & 20 & 6.01 & 4.62 & 3.12 & 2.35 & 1.97 & 1.85 & 1.97 & 2.35 & 2.61 & 3.29 & 4.42 & 5.22 \\
\hline Doha & 25 & 3.27 & 3.73 & 3.36 & 3.36 & 3.61 & 3.68 & 3.05 & 2.92 & 3.07 & 3.13 & 2.94 & 2.95 \\
\hline Cairo & 30 & 3.96 & 4.03 & 4.37 & 4.56 & 4.78 & 5.14 & 4.59 & 4.47 & 4.09 & 3.87 & 3.59 & 3.86 \\
\hline Tokyo & 35 & 5.01 & 4.66 & 3.96 & 3.90 & 3.27 & 2.33 & 2.20 & 2.31 & 1.70 & 2.45 & 3.52 & 4.83 \\
\hline New York & 40 & 3.79 & 4.22 & 4.38 & 4.20 & 4.16 & 4.10 & 3.62 & 3.56 & 3.64 & 3.91 & 3.43 & 3.50 \\
\hline Milan & 45 & 3.63 & 4.26 & 4.48 & 3.86 & 3.93 & 4.24 & 4.20 & 3.71 & 3.30 & 2.62 & 2.78 & 2.78 \\
\hline Frankfurt & 50 & 1.74 & 2.75 & 2.74 & 3.32 & 3.59 & 3.40 & 3.38 & 3.07 & 2.43 & 1.76 & 1.44 & 1.34 \\
\hline Copenhagen & 55 & 1.95 & 2.58 & 3.41 & 3.99 & 4.62 & 4.26 & 3.96 & 3.65 & 2.95 & 2.44 & 1.96 & 2.03 \\
\hline
\end{tabular}


Table 3 Optimum tilt angle, $\beta_{\text {opt }}$ (seasonal) for 12 cities globally

\begin{tabular}{lccccc}
\hline \multicolumn{1}{c}{ City } & Latitude & \multicolumn{3}{c}{ Optimum tilt angle, $\boldsymbol{\beta}_{\text {opr }}\left({ }^{\circ}\right)$ for season: } \\
& Angle $\left(^{\circ}\right)$ & Spring & Summer & Autumn & Winter \\
\hline Quito & 0 & 5 & 0 & 3 & 23 \\
Terengganu & 5 & 9 & 0 & 5 & 25 \\
Kupang & 10 & 13 & 0 & 11 & 42 \\
Lusaka & 15 & 17 & 0 & 14 & 46 \\
Vitória & 20 & 22 & 2 & 16 & 51 \\
Doha & 25 & 26 & 1 & 22 & 50 \\
Cairo & 30 & 32 & 2 & 27 & 59 \\
Tokyo & 35 & 36 & 10 & 28 & 67 \\
New York & 40 & 53 & 18 & 47 & 85 \\
Milan & 45 & 57 & 23 & 51 & 86 \\
Frankfurt & 50 & 60 & 30 & 55 & 86 \\
Copenhagen & 55 & 66 & 35 & 61 & 89 \\
\hline
\end{tabular}

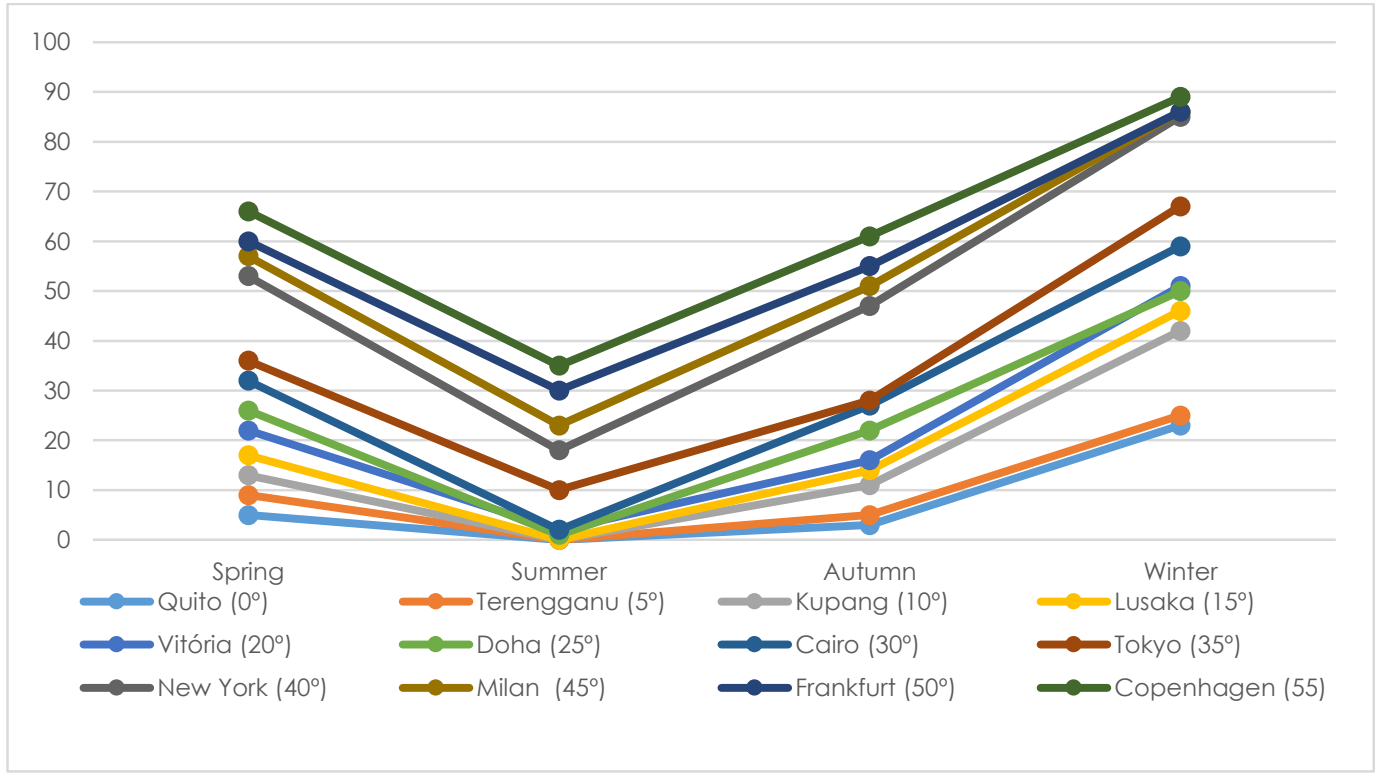

Figure 4 Optimum tilt angle, $\beta_{\text {opt }}$ for each season for 12 cities (located at different latitude angles)

Table 4 Annual average daily energy (seasonal) for 12 cities globally

\begin{tabular}{lccccc}
\hline $\begin{array}{l}\text { City/Energy } \\
\text { (MWh/day) }\end{array}$ & $\begin{array}{c}\text { Latitude } \\
\text { Angle } \mathbf{(}^{(} \text {) }\end{array}$ & \multicolumn{4}{c}{$\begin{array}{c}\text { Annual average daily energy output for season: } \\
\text { (MWh/day) }\end{array}$} \\
& Spring & Summer & Autumn & Winter \\
\hline Quito & 0 & 3.23 & 2.99 & 3.14 & 3.16 \\
Terengganu & 5 & 3.67 & 3.07 & 2.97 & 2.46 \\
Kupang & 10 & 3.91 & 3.47 & 4.83 & 5.73 \\
Lusaka & 15 & 3.96 & 3.79 & 4.83 & 5.53 \\
Vitória & 20 & 3.27 & 1.93 & 2.70 & 5.21 \\
Doha & 25 & 3.41 & 3.45 & 2.97 & 3.05 \\
Cairo & 30 & 4.22 & 4.84 & 4.05 & 3.80 \\
Tokyo & 35 & 4.06 & 2.60 & 2.11 & 4.45 \\
New York & 40 & 4.19 & 3.96 & 3.64 & 3.57 \\
Milan & 45 & 4.12 & 4.12 & 3.16 & 3.06 \\
Frankfurt & 50 & 2.89 & 3.46 & 2.39 & 1.51 \\
Copenhagen & 55 & 3.28 & 4.28 & 2.97 & 1.98 \\
\hline
\end{tabular}


Table $5 \beta_{\text {opt }}$ and annual average daily energy (yearly) for 12 cities globally

\begin{tabular}{lccc}
\hline \multicolumn{1}{c}{ City } & $\begin{array}{c}\text { Latitude } \\
\boldsymbol{\mathbf { \phi } ( { } ^ { \circ } )}\end{array}$ & $\begin{array}{c}\text { Optimum Tilt } \\
\text { Angle, } \\
\boldsymbol{\beta}_{\text {opt }}\left({ }^{\circ}\right)\end{array}$ & $\begin{array}{c}\text { Annual } \\
\text { Average } \\
\text { Daily Energy } \\
\text { (MWh/day) }\end{array}$ \\
\hline Quito & 0 & 0 & 3.08 \\
Terengganu & 5 & 3 & 2.98 \\
Kupang & 10 & 16 & 4.23 \\
Lusaka & 15 & 21 & 4.28 \\
Vitória & 20 & 31 & 3.11 \\
Doha & 25 & 22 & 3.04 \\
Cairo & 30 & 27 & 3.97 \\
Tokyo & 35 & 39 & 3.10 \\
New York & 40 & 53 & 3.66 \\
Milan & 45 & 56 & 3.46 \\
Frankfurt & 50 & 56 & 2.47 \\
Copenhagen & 55 & 62 & 3.01 \\
\hline
\end{tabular}

Table 6 Annual average daily energy (monthly, seasonally, yearly) for 12 cities globally

\begin{tabular}{lccccc}
\hline $\begin{array}{l}\text { City/Energy } \\
\text { (MWh/day) }\end{array}$ & Monthly & Seasonally & Yearly & $\begin{array}{c}\text { Gain (\%) } \\
\text { Monthly }\end{array}$ & $\begin{array}{c}\text { Gain (\%) } \\
\text { Seasonally }\end{array}$ \\
\hline Quito & 3.14 & 3.13 & 3.08 & 1.91 & 1.59 \\
Terengganu & 3.07 & 3.04 & 2.98 & 2.93 & 1.97 \\
Kupang & 4.54 & 4.48 & 4.23 & 6.82 & 5.58 \\
Lusaka & 4.58 & 4.52 & 4.28 & 6.55 & 5.30 \\
Vitória & 3.31 & 3.28 & 3.11 & 6.04 & 5.18 \\
Doha & 3.26 & 3.22 & 3.04 & 6.74 & 5.59 \\
Cairo & 4.28 & 4.22 & 3.97 & 7.24 & 5.92 \\
Tokyo & 3.34 & 3.30 & 3.10 & 7.18 & 6.06 \\
New York & 3.88 & 3.84 & 3.66 & 5.67 & 4.68 \\
Milan & 3.65 & 3.62 & 3.46 & 5.20 & 4.41 \\
Frankfurt & 2.58 & 2.56 & 2.47 & 4.26 & 3.51 \\
Copenhagen & 3.15 & 3.12 & 3.01 & 4.44 & 3.52 \\
\hline
\end{tabular}

From the results, the monthly and seasonal $\beta_{\text {opt }}$ can maximize the generated output energy from the LSS system for most locations during its 25 years life time. However, it still depends on both of the location and the local climatic conditions (solar radiation, sunshine hours, temperatures, humidity, etc.). Therefore, it is highly recommended to recalculate the exact value of the $\beta_{\text {opt }}$ at least once per year to ensure the accuracy of its value based on the continuously varying local climatic conditions.

\subsection{CONCLUSION}

This paper has simulated the impact of monthly and seasonal optimum tilt angle, $\beta_{\text {opt }}$ of solar PV panel on electrical energy output of a 1MW LSS plant. The results were compared to the LSS system with a fixed Bopt. From the results of 12 cities, it can be concluded that the optimum tilt angle, $\beta_{\text {opt }}$ could increase the generated energy output between $1.91 \%$ and $7.24 \%$ for monthly adjustments and between $1.59 \%$ and $6.06 \%$ for seasonal adjustments. These findings will help engineers to optimize the design and operation of the LSS plant to maximize the electrical energy output.

\section{Acknowledgement}

This research was supported by the Ministry of Higher Education (MOHE), Malaysia and Universiti Teknologi Malaysia (UTM) through the Research University Grant (UTMShine) vot. 04G45. Special thanks to my Dear Supervisor Prof. Dr. Wagdy R. Anis who is the main contributor to create the main MATLAB code during my Master research at Faculty of Engineering, Ain Shams University, Cairo-Egypt.

\section{References}

[1] T. M. Yunus Khan et al. 2019. Optimum Location and Influence of Tilt Angle on Performance of Solar PV Panels. J. Therm. Anal. Calorim. Doi: 10.1007/s10973-019-09089-5.

[2] G. Hailu and A. S. Fung. 2019. Optimum Titt Angle and Orientation of Photovoltaic Thermal System for Application in Greater Toronto Area, Canada. Sustain. 11 (22). Doi: 10.3390/sul 1226443. 
[3] M. Dhimish and S. Silvestre. 2019. Estimating the Impact of Azimuth-angle Variations on Photovoltaic Annual Energy Production. Clean Energy. 3(1): 47-58. Doi: 10.1093/ce/zky022.

[4] N. Adibah Ayuni Abd Malek, J. Ming Chew, N. Akmam Naamandadin, N. Zaiha Zainol, and K. Muhammad. 2018. A Study on Association between Tilt Angle, Solar Insolation Exposure and Output of Solar PV Panel using BIM 3D Modelling. MATEC Web Conf. 195. Doi: 10.1051/matecconf/201819506009.

[5] M. Z. Jacobson and V. Jadhav. 2018. World Estimates of PV Optimal Tilt Angles and Ratios of Sunlight Incident upon Tilted and Tracked PV Panels Relative to Horizontal Panels. Sol. Energy. 169(December 2017): 55-66. Doi: 10.1016/j.solener.2018.04.030.

[6] S. J. M. Shareef. 2017. The Impact of Tilt Angle on Photovoltaic Panel Output. Zanco J. Pure Appl. Sci. 29(5). Doi: 10.21271/zjpas.29.5.12.

[7] M. Guo et al. 2017. Optimal Tilt Angle and Orientation of Photovoltaic Modules using HS Algorithm in Different Climates of China. Appl. Sci. 7(10). Doi: 10.3390/app7101028.

[8] H. Singh. 2017. Effect of Surface Conditions and Tilt Angle of Solar Photo-voltaic Panel on Power Output. 6(6): 232-237.

[9] M. A. Islam, M. S. Alam, K. K. Sharker, and S. K. Nandi. 2016. Estimation of Solar Radiation on Horizontal and Tilted Surface over Bangladesh. Comput. Water, Energy, Environ. Eng. 05(02): 54-69. Doi: 10.4236/cweee.2016.52006.

[10] A. Karafil, H. Ozbay, M. Kesler, and H. Parmaksiz. 2016. Calculation of Optimum Fixed Tilt Angle of PV Panels Depending on Solar Angles and Comparison of the Results with Experimental Study Conducted in Summer in Bilecik, Turkey. ELECO 2015 - 9th Int. Conf. Electr. Electron. Eng. 971-976. Doi: 10.1109/ELECO.2015.7394517.

[11] B. Jamil, A. T. Siddiqui, and N. Akhtar. 2016. Estimation of Solar Radiation and Optimum Tilt Angles for South-facing Surfaces in Humid Subtropical Climatic Region of India. Eng. Sci. Technol. an Int. J. 19(4): 1826-1835. Doi: 10.1016/j.jestch.2016.10.004.

[12] H. Zang, M. Guo, Z. Wei, and G. Sun. 2016. Determination of the Optimal Tilt Angle of Solar Collectors for Different Climates of China. Sustain. 8(7): 1-16. Doi: 10.3390/su8070654.

[13] T. Khatib, A. Mohamed, M. Mahmoud, and K. Sopian. 2015. Optimization of the Tilt Angle of Solar Panels for Malaysia. Energy Sources, Part A Recover. Util. Environ. Eff. 37(6): 606-613. Doi: $10.1080 / 15567036.2011 .588680$.
[14] R., S. K. Suman. 2015. Effect of Tilt angle and Azimuth Angle on Solar Output and Optimum Tilt and Azimuth Angle for Chandigarh, India. Int. J. Adv. Res. Electr. Electron. Instrum. Eng. 4(6): 5104-51 10. Doi: 10.15662/jareeie.2015.0406028.

[15] M. Fadaeenejad, M. A. M. Radzi, M. Fadaeenejad, M. Zarif, and Z. Gandomi. 2015. Optimization and Comparison Analysis for Application of PV Panels in Three Villages. Energy Sci. Eng. 3(2): 145-152. Doi: 10.1002/ese3.52.

[16] S. M. Salih and L. A. Kadim. 2014. Effect of Tilt Angle Orientation on Photovoltaic Module Performance. ISESCO J. Sci. Technol. 10(17): 19-25.

[17] B. Kamanga, J. S. P. Mlatho, C. Mikeka, and C. Kamunda. 2014. Optimum Tilt Angle for Photovoltaic Solar Panels in Zomba District, Malawi. J. Sol. Energy. 1-9. Doi: 10.1155/2014/132950.

[18] E. Calabrò. 2013. An Algorithm to Determine the Optimum Tilt Angle of. J. Renew. Energy. 12.

[19] J. Dunlop. 2012. Solar Radiation Terminology \&amp; Definitions. Chapter 2.

[20] N. Shu, N. Kameda, Y. Kishida, and H. Sonoda. 2006. Experimental and Theoretical Study on the Optimal Tilt Angle of Photovoltaic Panels. J. Asian Archit. Build. Eng. 5(2): 399-405. Doi: 10.3130/jaabe.5.399.

[21] P. Tsalides and A. Thanailakis. 1985. Direct Computation of the Array Optimum Tilt Angle in Constant-tilt Photovoltaic Systems. Sol. Cells. 14(1): 83-94. Doi: 10.1016/0379-6787(85)90008-0.

[22] Mohamed Nageh, Wagdy, R. Anis and Ismail, M. Hafez. 2015. A Proposed Solution for Partial Shadowing. International Joumal of Computer Applications. 121 (18): 28-38.

[23] Tiwari, Gopal Nath, and Swapnil Dubey. 2010. Fundamentals of Photovoltaic Modules and Their Applications. No. 2. Royal Society of Chemistry,

[24] Fröhlich, C., and R. W. Brusa. 1981. Solar Radiation and Its Variation in Time. Physics of Solar Variations. Springer Netherlands, 209-215.

[25] Duffie, J. A., \& Beckman, W. A. 1980. Solar Engineering of Thermal Processes. Vol. 3. New York etc.: Wiley,

[26] Klein, S. A. 1977. Calculation of Monthly Average Insolation on Tilted Surfaces. Solar Energy. 19(4): 325-329,

[27] Cooper, P. I. 1969. The Absorption of Radiation in Solar Stills. Solar Energy. 12(3): 333-346. 